\title{
17
}

\section{Carl Georg von Brandenstein's legacy: The past in the present}

\author{
Nick Thieberger ${ }^{1}$
}

Interned as a prisoner of war in Australia in the 1940s, the Hittite specialist Carl Georg von Brandenstein went on to work with speakers of a number of Australian languages in Western Australia. At a time when the dominant paradigms in linguistics were either Chomskyan reductionism or writing a grammar to the exclusion of textual material, Carl followed his own direction, producing substantial collections of texts and recordings in Ngarluma, Yindjibarndi, Nyiyaparli, Ngadju and Noongar, as well as information about a number of other Australian languages. Part of his motivation was to obtain examples to reconstruct what he considered to be the original human language that diffused to all corners of the world, so he put some effort into comparing Australian languages with the classical languages he had previously studied. He published on the nature of kinship and section systems, aligning characteristics similar to medieval European humours, and then extending that to the notion of active (nominative) and passive (ergative) verbal concepts. He interpreted symbolism in designs and in the categories and sounds of the languages he recorded. He was also convinced that Portuguese explorers had settled on the west coast of Australia and received public attention for his claims,

1 Thanks for reminiscences and other help to Reuben Brown, Pat Engberg, Erich Kolig, Jacqie Lambert, Merrin Mason, Anthony McCardell, Kirsty Murray, Ursula Oehme, Frank Rijavec, John Stanton, Dina and Henry Thieberger (for translations) and Anthony Thomas. Parts of this work have been supported by Australian Research Council grants DP0984419 and FT140100214. 
which were partly based on comparisons of words from Pilbara languages with Portuguese. In Thieberger (2008), I showed that most of Carl's claims of Portuguese influence could not be substantiated, but, in this chapter, I will discuss the value of Carl's work despite the anachronous theoretical models that drove him. Since I wrote that earlier work, more details of Carl's life have emerged, which are included here.

\section{Carl's studies and formation}

Carl was educated in Berlin and Leipzig in the 1930s as a specialist in ancient Eastern studies and the history of religion (Altorientalist mit Religionsgeschichte) with two years of practical work at the Berlin Ethnological Museum. He began work on the Hurrian language, which was to be the topic of his habilitation, but the war intervened and he thought his material was lost in the war. He went to Persia with the German Army, was captured by the British in September 1941 and interned at Loveday and Tatura camps in Australia. His immigration documents list him as working for a pharmaceutical company and then, probably as a result, his profession is listed as 'pharmacist' - a fiction that was maintained in these documents until after the war-but his internee documents note that he was in counterintelligence and his own brief biographical notes make no mention of pharmaceuticals or pharmacy, but say he was in the Canaris Gruppe, an intelligence unit that was later involved in a failed attempt to assassinate Hitler.

An interview with Australian military authorities on 15 May 1946 resulted in the following 'character sketch':

He admitted that earlier he had been very much impressed with Nazism which had brought economic order out of chaos. His enthusiasm however received a jolt when the pledge of 'No War' was not honored, but loyalty to his country stimulated a fervid hope for German success. Since the end of the war he has been disillusioned concerning the Nazi owing to the various facts revealed in the news, which he thinks cannot be all propaganda. He has been very much impressed with Australia and earnestly desires to remain here, is prepared to be naturalised and serve this country with the same fervor as he supported Nazism ... He wishes to keep as far as possible from politics of all kinds, blames his extreme youth for earlier enthusiasm. A most desirable type, cultured and a serious thinker. ${ }^{2}$

2 E. A. T. Sgt Interpreter, Series A1838 1451/2/47, 15 May 1946, National Archives of Australia [NAA], Canberra. 
Following internment, he refused paid repatriation to Germany in November 1947 and elected to remain in Australia, according to a memo to the Australian Military Mission, Berlin, from the internment camp authorities. This memo was in response to a request from Carl's wife (who, with their daughter, was left in Berlin when he was interned) asking why he could not be repatriated.

He is alleged to have told his wife that much as he would like to return to her he cannot be repatriated, and he has not enough money to pay his own fare to Germany. ${ }^{3}$

At the time (September 1949), he had an address in west Melbourne.

He worked in the post office and also with Arthur Boyd in the 1950s, and then lived in New Zealand, where his second wife, Carola, worked at the German Embassy in Wellington, but there is not much more information about his life until he started working with Aboriginal people in Western Australia. According to a letter ${ }^{4}$ by Dianne Barwick to Frank Gare, Commissioner for Native Welfare (dated 28 May 1964), 'Dr von Brandenstein did field studies of Aranda in 1959 and Western Desert languages in 1962 and 1963'. In his notes, Carl says he did a fieldtrip to Laverton at his own expense. I have been unable to find any records resulting from these earlier fieldtrips. During the 1960s, he received grants from the Australian Institute of Aboriginal Studies (AIAS; later renamed the Australian Institute of Aboriginal and Torres Strait Islander Studies: AIATSIS). These grant proposals were reviewed and received positive reports-for example, T. G. H. Strehlow noted that 'I am in favour of a renewal of his grant'. ${ }^{5}$ Berndt observed that: 'Kept to his direct language survey, and actual recording, he does very well—but (as Capell will know) he is not structurally oriented and is philologically focused. ${ }^{6}$

3 Series A1838, Memo 103, 1451/2/4/7, 20 March 1950, NAA.

4 In Registry files, Australian Institute of Aboriginal and Torres Strait Islander Studies [AIATSIS], Canberra.

5 Strehlow review to AIATSIS, 11 March 1965, AIATSIS.

6 Berndt letter to McCarthy, 22 February 1965, AIATSIS. 


\section{My connection to Carl}

I met Carl on several occasions in the 1980s when I was working on a survey of West Australian Aboriginal languages (Thieberger 1993). He was very helpful in providing access to his work and we continued to correspond over the years. As I got more interested in the role of primary records of language performance in linguistic research, and the need to prepare and present the primary material together with the analysis, I found that Carl was one of the only linguists to provide such a connection, publishing a $45 \mathrm{rpm}$ record with his texts of Ngarluma and Yindjibarndi (von Brandenstein 1970b). His interest in producing texts in Aboriginal languages, albeit written in his own orthography, meant that there are now sets of texts for Ngarluma, Yindjibarndi, Nyiyaparli and Ngatju (other languages included in his work are Mirning, Pitjantjatjara, Ngaanyatjara, Mardutjara, Manyjilyjara, Warnman, Dargudi, Nyiyapali, Nyamal, Inggarda, Jurruru, Warriyangka, Jiwarli/Thiin, Purduna, Payungu, Thalanyji, Pinikura, Martuthunira, Ngalawanga, Panyjima and Kurrama).

In 1999, AIATSIS asked me to visit Carl's house in Albany, Western Australia, to assess what was there and to suggest what should happen to it all. I was unable to find much of his primary research material and have been on the hunt for it ever since. I visited him in the local nursing home and had a conversation of sorts with him (he was already severely affected by dementia). I used his material in the linguistic reports for the single Noongar native title claim and for the Ngarluma/Yindjibarndi native title claim. A task for the linguist in these court processes is to show continuity of the language over time (since colonial 'sovereignty'). Carl's work was some of the most recent documentation of the languages, providing a basis for comparison with the earliest sources, and, in both cases, showing undeniable linguistic continuity over that period.

\section{The themes in his work}

The words used in reviews of Carl's work indicate the range of reactions it elicited-they include 'fanciful', 'unfashionable', 'rash', 'fantasy', 'cultural bric-a-brac', but also 'plausible'. We need to distinguish his earlier period, with fieldwork and writing up of results as a major focus, from his later writing, which became increasingly more speculative with time. 
What did Carl's earlier work on Hittite iconography bring to his study of Australian languages? In part, he continued his interest. For example, in his article on 'The symbolism of north-western Australian zigzag design' (von Brandenstein 1972), in which he associated river directions with shield designs, he included images from fourth-millennium Egyptian design that also uses zigzags and made references to Mesopotamian art in which water is designed using curves, without sharp angles. This juxtaposition is not elaborated on in this article, which concludes: 'The identical zigzag line or band as a symbol of water was already known in ancient Egypt, from predynastic times on, whilst Mesopotamia had nothing like it to offer' (von Brandenstein 1972: 238). This might seem to imply that humanity's development of the zigzag pattern-'already known in ancient Egypt - was somehow then diffused to all humans, but it is left more as a suggestion here than an overt statement. This interweaving of themes from the Old World with Indigenous Australia would be a continuing theme throughout his research in Australia.

I have asked specialists in Hurrian about Carl's work and had this response from Miroslav Salvini:

I remember very well the works of Carl Georg von Brandenstein, especially the articles about the Hurrian language and the volume KUB XXVII [von Brandenstein 1934]. They were among the few Hurritological contributions at our disposal, when our Berlin Group began in the '60s the study of that language and the work at the Hurrian Corpus. ${ }^{7}$

For us $\mathrm{vBr}$ belonged to the prehistory of Hurritology, a branch of Hittitology which we renewed. The most recent book in Hurritology still quotes 'Zum Churrischen Lexikon' by von Brandenstein. Undoubtedly he left a mark in Hurrian and Hittite (cf. e.g. Bildbeschreibungen) studies. ${ }^{8}$

Carl's work had a mixed reception among his professional peers. He was motivated to show diffusion, claiming that changes in language and culture are the result of contact from a single source spread through the world - in the particular case of Australia, by African slaves and Portuguese establishing colonies in north-western Australia. As I noted in Thieberger (2008), he regarded the languages of the world as having a pattern like a carpet, with the most worn areas of the carpet revealing the least about

7 Salvini, personal communication, 19 May 2015.

8 ibid., 22 May 2015. 
the original pattern. In this view, the most traffic is in Europe, hence the need to study languages at the edges of the carpet, of which Australian languages, he posited, were an example.

A linguistic feature that was the focus of several of Carl's publications was what he called the 'active verbal concept' (AVC) and the 'passive verbal concept' (PVC). He thought the PVC (what is more commonly known as the ergative case, which marks the transitive subject only) was historically prior and the reflection of a 'language family' (von Brandenstein 1967: 5), the sole survivor of which in Europe was Basque. He suggested that the change to the AVC in some parts of Australia manifested 'as the result of a change to more individualistic thinking'. There is no evidence provided to link these, nor of what he means by 'individualistic thinking', but it is indicative of his view of the deterministic role of language in shaping culture. Yallop, in a review, noted:

Not every reader will be willing to accept, for example, von Brandenstein's explanation of a linguistic change 'as the result of a change to more individualistic thinking' but we do well to ask ourselves whether von Brandenstein is wrong or merely unfashionable. (Yallop 1974: 86)

In the following passage, we see the linking of languages that are geographically widespread and quite unrelated but are regarded as part of a single family due to the presence of one grammatical feature, the PVC. The inclusion of Māori is quite peculiar, as we know that the Polynesian language family is relatively young, certainly in comparison with Australian languages:

In the Caucasus ... Churrian and Biainian formed the oldest PVC group known ... Today the only PVC language of a similar type is the NorthCaucasian Dagestan language Avaric with about 170,000 speakers, whilst Georgian, of the South-Caucasian group, stands more apart. If we look further east it is interesting to note in connection with the fate of the PVC allies of the conquerors of India, that a PVC substratum, apparently dormant until the 13th century (A. D.), has eventually reproduced PVC features in modern offspring like Hindi, Benghali, Nepali, etc. Going south-east we come across traces of PVC on Timor and-returning for a moment to Australia-we find PVC prevailing over a large part of the Suffixing Languages of the interior, perhaps the best known being the Western Desert group. Leaving aside an ambiguous brand of PVC in Indonesia and the Philippines we have, further east, the widespread Polynesian group, well illustrated by its eastern branch Maori. Finally we reach South America and close our list with Kechua in Peru and neighbouring states. (von Brandenstein 1967: 5) 
The overall implication is that languages remain static unless influenced by some external force and, in the case of the north-west coast of Australia, this is the arrival of the Portuguese. Carl's field report in August 1965 is the first mention of the term 'tartaruga' for turtle, with the note that it has been 'brought to the North Western shores between the De Grey and Nichol Bay by the Portuguese, less likely by the Late Romans' (von Brandenstein 1965: 2).

Baxter (1996: 300), in his work on Portuguese creoles in the region, points out that the crews of Portuguese ships were typically Asian and African slaves, thus it is unclear how much Portuguese would have been spoken. Nevertheless, even if it were Portuguese, the evidence provided by Carl may be restricted to the word 'tartaruga'. He offers conjecture about the origin of this term, noting that:

Although it seems absurd to consider, even as a last possibility, the origin of tartaruga and its spread to Europe during the Great Peoples' Migration by returning Roman, Greek or Teutonic seafarers, it should at least be mentioned. In this connection I have hesitantly to draw attention to a considerable number of genuine Australian word-stems which could be connected easily with Romance resp. Indo-European stems. (von Brandenstein 1967: 15)

Von Brandenstein (1970b) lists 60 'north-west' words that he claims derive from Portuguese. If we attempt to locate the same forms in other wordlists of Ngarluma (e.g. Hale 1982) or Yindjibarndi (e.g. Wordick 1982) (together denoted as NW-'north-west'-below), we can find, with a generous interpretation of similarity, only 23 of the 60 and, even then, there would need to be some explanation of semantic shifts that have taken place (e.g. Portuguese 'angle' to NW 'elbow'), or of why he considered there to be a relationship at all (e.g. Portuguese 'mortal, NW 'marlba'). Most importantly, there are terms included in this list that are widespread in Australia. They are unlikely to have originated in the northwest and can be regarded as only coincidentally similar (e.g. Portuguese ' $m a \tilde{o}$ ', NW 'mara'). Beyond the borrowing of a word, he offers the following vision of a changed social organisation among the Ngarluma as a result of the alleged contact with the Portuguese. It is very unclear whether this is something he was told about or something he observed:

The Ngarluma and, most likely also, the Karriera were exceptional and unaboriginal not only linguistically. Their spinifex seed harvest method is socially and technologically far advanced compared with the seed 
gathering practices of other Aboriginal tribes. Under the supervision of specially appointed elders, the whole tribe, young and old, male or female, were equipped with specifically made cylindrical bark containers of equal height and diameter, to be filled by everyone with spinifex seeds (Triodia sp.). The full containers were delivered, checked and emptied at suitably situated caves, dry and cool and under constant guard; the contents were stored there until the time of need. The distribution was likewise strictly organised according to the principles of social justice, with age before youth. The Ngarluma never suffered from seasonal setbacks of grain supply. I suggest that this organisation was introduced by Portuguese elements of the Ngarluma population. (von Brandenstein 1989: 11-12)

The theory of Portuguese contact, settlement and ongoing cultural and linguistic influence was to drive Carl's later work, reaching its most peculiar in two manuscripts (von Brandenstein n.d., 1994), from the latter of which the following is part of the front matter:

The chosen title Early History of Australia is, above all, clearly showing where the main interests and greatest chances of being successful must naturally lie: on a new and unique field of linguistics in North-Western and Northern Australia, involving Portuguese with Criolo and Creole, West-African Ful with nomadic Bororé-be'e cattlemen's 35-class-language, and the Bururú-biri's 3-, 4- and 5-class-languages in the Kimberley and related class-languages in Northern Australia (Arnhem Land); as well as Vulgar Latin, Old Indian, Iranian and Maghreb Arabian loan words in Aboriginal languages of Western Australia and Western Victoria. (von Brandenstein 1994: 5)

Note that the claims now also include Victorian languages, but with no indication of how the loan words travelled so far, what intervening steps there may have been and what traces they should have left. To be fair, at this stage of his life, Carl was soon to be committed to hospital care with dementia.

Among the themes he returned to in his work was the notion of sound symbolism or phonaesthesia. So, in his grammar of Ngadjumaja (southeast Western Australia), he discusses the 'static a and the dynamic u'; similarly, in the Ngarluma texts, he lists 'a' as static, ' $\mathrm{u}$ ' as dynamic and ' $\mathrm{i} / \mathrm{e}$ ' as neutral (von Brandenstein 1970b: 301). Elsewhere, he talked of ' $\mathrm{k}$ ' as the phonoseme of 'aggression', of ' $m$ ' as 'finite distance' and ' $w$ ' as 'infinite distance'. Again, it is unclear whether he is reporting on Indigenous ideas about these sounds or whether it is his own interpretation. He also wrote of the influence of environmental factors on the articulation of 
Aboriginal languages, in which "prevailing aridity would "dehydrate" the saliva-consuming sibilants and leave their functions to the dental palatal' (von Brandenstein 1980: 5). There are no sibilants (fricatives) in any southern language, but only a small number of these languages are spoken in arid zones; many are spoken in coastal or mountain regions. So the claim that aridity leads to a loss of sibilants would have to also suggest that the parent language was spoken in an arid region and that the descendant languages then inherited that characteristic. This is simply not tenable.

His theory of diffusion led him to look for similarities between widely separated (both geographically and genetically) languages, as in the following example in which he notes:

the Finno-Ugrian essive-na is identical in form and function [to the Ngadumaja essive- $\mathrm{N}$. T.]. The full range of functions of the Australian essive-na, ńa, -ni is met again in Churrian and Bianian, two ancient cognate languages from eastern Asia Minor. (von Brandenstein 1980: 21)

There is some merit in showing typological similarities between languages and in showing that features under examination in one language appear in other languages with the same or similar functions. However, the emphasis of Carl's work is on revealing origins of language, with examples of similarities implying common origins. The collocation of FinnoUgrian and Australian examples, while never explicitly stated as being genetically related, implies relationships that Carl was keen to expose: 'I have hinted earlier ... that Finno-Ugrian and Aboriginal Australian have more in common than just typological superficialities' (von Brandenstein 1970b: 298).

The distinction mentioned earlier between active and passive (or nominative/ergative) is one that Carl observed as having resonance more broadly: "The whole world, preferably of animals and humans, is divided into the opposed temperaments "active" and "passive" (von Brandenstein 1977: 171). This is aligned with two moieties in Noongar (south-west Western Australia), Corella and Raven. Carl then provides a four-page list of various plants and animals or 'totems' and their moieties, recorded with Charlie Dab of Esperance. He reports on characteristics of these and briefly extends the classification to section systems of kinship elsewhere in Australia. This was followed up in von Brandenstein (1970a), where he makes a plea for universal classification, appealing to the attempts at classification of 'human temperaments and somatic types' begun in the eighteenth century but failing to achieve its 
goals in the scientific twentieth century, while the great achievement of early mankind'-the recognition of essential temperaments associated with kinship categories-'still towers in the far distance of prehistory, unequalled and hardly known' (von Brandenstein 1970a: 49).

Carl elaborated this analysis in his 1982 book, Names and Substance of the Australian Subsection System, in which he suggests Karierra as the source for this kind of totemic affiliation:

[I]f the substance of the Karierra section system is complex classification by opposed temperamental qualities, similar systems in other areas of Australia must likewise be based on the same contrast of temperaments ... The rationale behind it must be expected to have remained of one cast and unchanged for ages. To think otherwise would mean to fail to gauge the substance of the eternal Aboriginal dream-time exactly, by applying again our old European yardstick, overworked as it is for measurement of 'change'. (von Brandenstein 1982: 5)

Yengoyan's review of this work notes:

[W] hat is missing is any attempt to understand what are the linguistic and cultural processes in which the transformation and shift in terminology is accomplished from one society to another. (Yengoyan 1984: 346)

Heath's (1984: 466-7) review of the book says the overall argument is plausible and recommends the book to anyone interested in anthropological philology and structuralist theories of culture. Jorion's (1983: 794) review, on the other hand, says 'von Brandenstein's reconstructions of the ethnography are quite rash'.

While emphasising the importance of collecting primary records in Australian languages, Carl's analysis of this material was often significantly flawed. McConvell (1985: 61) details a number of errors made in the work on section names: 'Much of his linguistic evidence is coincidence, dressed up as historical connection.' He goes on:

Von Brandenstein's approach contents itself with letting ... crucial pieces of the puzzle go unsolved, while the collection of vaguely interesting cultural bric-a-brac, which neither proves nor disproves anything, is given priority. (McConvell 1985: 63) 
The diffusionist nature of his argument can be seen in the following statement in his chapter on the 'Identical principles behind Australian totemism and Empedoclean "philosophy" (von Brandenstein 1978):

We have established as a fact the identity of the totemic classification system of the Australian Aborigines, in particular of the Karierra, with the elementary classification system handed down from primeval times in Greece by Empedocles ...

It should be kept in mind what an immense area of this planet had once been invaded and covered by the doctrine of the four basic qualities and been brought under the rule of the totemic order. Signs of it can be found in all continents. The author assumes that totemism has been the Weltanschauung of hunters and gatherers for thousands of years. The further the mode of living became removed from the original one of huntsmen in the course of strife and development, the more blurred or inflated with alien practices its fabric must have appeared.

The fifth continent was spared historical upheavals most and therefore could preserve the social part of the totemic heritage the purest. The battered or shaken frontier between Asia and Europe, cutting right through the ancient Greek world, has been most successful in transforming totemism and passing on its essence to us Europeans. (von Brandenstein 1978: 143)

Morphy's review of the volume in which this chapter appeared says:

Taken as a whole the volume is of uneven quality, varying from papers that make a genuine contribution to contemporary anthropological theory to ones that evoke not too happy memories of a bygone era ... Von Brandenstein's paper on 'Identical principles behind Australian totemism and Empedoclean "philosophy"' is not credible, more rude than erudite. (Morphy 1979: 79)

Leaving his analysis of totemism and kinship, let us return to Carl's linguistic fieldwork. He spent a decade travelling through the Pilbara and recorded many audiotapes (AIATSIS has at least 39) with speakers of a range of Indigenous languages (listed later in this chapter). In his book of Tabi song and poetry, Taruru (von Brandenstein and Thomas 1974), he aims to show the lyrical nature of the allusions appealed to by the composers and performers. It is unclear how much poetic licence he applied to the interpretation of the lyrics, but it could be argued that he discussed the meaning with the performers to arrive at his translations. 
In fact, as noted earlier, it is a common frustration with Carl's work that it is unclear how a certain result has been obtained and on what kind of evidence it is based. Elkin's (1975: 244) review of Taruru concludes:

Dr. Brandenstein did Aboriginal Studies noteworthy service in recording the music and text of the tabi, and in providing the notes on each of the songs, including native text, word-for-word translation, and the comments on the singers and material ... This is a welcome addition to the Australian Aborigine's own literature.

Nash (1982), in a review of the book Ngadjumaja (von Brandenstein 1980), praises the emphasis on texts, recognising the value of the work despite having some criticisms.

\section{Interactions with colleagues}

Despite his theories being so out of step with anyone else's work of the time, Carl nevertheless had financial support in the 1960s from the AIAS. This allowed him and Carola to drive from Perth to the Pilbara, spending around three months a year in the field. In the early to mid1960s, he worked in the Gascoyne and Pilbara regions. Later, the couple was in the Goldfields and Esperance areas. Their base was an office in the anthropology department at the University of Western Australia, provided by Ronald Berndt, until 1970, when Berndt and von Brandenstein's relationship had broken down, with Carl feeling that he was not being treated with sufficient respect.

Professor R. M. W. Dixon's arrival as the chairman of the Linguistics Committee at the AIAS signalled a change in attitude to Carl's work (as I have written about in Thieberger 2008). So, for example: 'you build your etymological hypotheses into all of your transcriptions so that, in a nutshell, one cannot distinguish fact from fancy.' However, as discussed earlier, all of Carl's work has been reused and can be interpreted and made useful to various kinds of language projects. The AIAS published the three-volume collection of texts in Ngarluma and Yindjibarndi (von Brandenstein 1970b), and Hale’s (1971) review notes:

9 Dixon letter to von Brandenstein, 15 March 1973, AIATSIS. 
The few reservations I have about these materials are not serious and do not detract from their value, in my opinion, I hope that the Australian Institute of Aboriginal Studies continues to publish material of this sort. (Hale 1971: 1369)

In fact, the institute subsequently refused to publish the sister volumes in Nyiyaparli. As Carl noted in correspondence:

$\mathrm{I}$, as a Member of the Institute and colleague, expect you as the Linguistics Committee Chairman to speed up my unduly delayed publication of NNW II for which conditions and arrangements had been approved by the Institute prior to your commencement of office. ${ }^{10}$

The correspondence between Carl and the AIAS, on the one hand, and Ronald Berndt, on the other, became increasingly strongly worded over time. Carl felt he was not being accorded due respect. In response, Berndt had this to say:

Let me be quite frank, which I am sure you will appreciate, I personally think you are being very silly about this whole business: you are too ready to take offence, when none is intended. I have supported you for several years now, and-in my view-your rebuff is not in good taste. Don't 'stand on your high horse', especially where goodwill is to be found. And do be sensible and try to see my point of view and appreciate that I am helping you as best I can. And we expect you at the Christmas party on the $17 \mathrm{th}$. All I can do is to assure you that no one is trying to get at you. ${ }^{11}$

\section{The mystery of Carl's missing notes}

When I visited Carl's house in Albany in 1999, I could not find much of the material that should have been there, including his notes, copies of publications and recordings. As early as 1974, Peter Sutton, in his role as an AIAS staff member, asked Carl about the diaries that 'do not include your data on the southern languages'. ${ }^{12}$ The falling out with the AIAS (Thieberger 2008) seems to have resulted in Carl not depositing his field records there. In June 2015, I learned from Erich Kolig (at the conference at which this chapter was presented) that a woman who claimed to have been Carl's wife had been in touch with him for advice about where to

10 Von Brandenstein to Dixon, 15 April 1973, AIATSIS.

11 Berndt's lettter to Carl, 16 December 1970 (about Carl's claims he was not being offered proper office space), Berndt Museum.

12 AIATSIS Registry 64/4, letter from Peter Sutton to Carl, 12 February 1974, AIATSIS. 
deposit Carl's material. I had spoken with her several times in the early 2000s when it seemed she had taken all of his material. Perhaps she saw me as an agent of AIATSIS and so was reluctant to reveal her possession of Carl's work. Happily, she followed the advice of Erich Kolig and deposited the papers at the Anthropos Bibliothek in Sankt Augustin, Germany. Thus, what had been the mystery of the location of these papers for some 40 years was now resolved.

\section{Contribution}

Having reached this point, you may well ask, why bother with this rather chaotic legacy? First, because there is great value to Carl's work that needs to be given its proper place in the history of Australian linguistics. Further, there is great public interest in possible early European contact with Australia (see, for example, Derriman 1990, 1992) and the evidence needs to be addressed and evaluated properly and not just dismissed.

But, most importantly, the valuable material in Carl's work can be separated from his personal theories, his spelling system can be deciphered and the texts, recordings and dictionaries he produced can be and have been reused, which is of huge value to the speakers he recorded and their descendants. His published narratives (von Brandenstein 1970b) in Ngarluma and Yindjibarndi from five speakers include topics ranging from practical knowledge ('Cutting up the kangaroo', 'How I prepare tobacco for chewing', 'Catching the dugong'), through the use of increase sites ('Smallpox talu', 'Snake talu', 'Paperbark blossom talu'), history ('Ambush at George River', 'Former war parties'), to origin stories ('Origin of Warmalana [Depuch Island]', 'A sea serpent made Millstream Pools') and a range of other themes.

The past in Carl's present was the diffusionism that was a constant theme, but also the rejection of what he perceived as being reductionist positivism, and what others saw as a lack of evidence for many, if not most, of his claims. He appears to have been an aristocrat with the time to pursue his theories unconstrained by the need for rigour or for the academic approval of others and used what could be termed statements from authority (ipse dixit) rather than testable arguments based on observable evidence. His later publications were not peer reviewed and were either self-published or produced as typescripts that he distributed to colleagues in an attempt to bring them over to what became his crusade. 
There is much more to Carl's lifetime of recording and writing than can be presented here. Today, he could be a postmodern bricoleur, putting together odds and ends of cultural observations and daring the reader to believe it.

As I hope I have shown, Carl made a great contribution to our knowledge of Australian languages and created records for those languages that will be treasured into the future.

\section{References}

Baxter, A. N. 1996. Portuguese and Creole Portuguese in the Pacific and the western Pacific Rim. In Atlas of Languages of Intercultural Communication in the Pacific, Asia and the Americas, (eds) S. A. Wurm, P. Mühlhäusler and D. T. Tryon, pp. 299-338. Berlin: Mouton de Gruyter. doi.org/10.1515/9783110819724.2.299.

Derriman, P. 1990. Why Western Australia's Aborigines are speaking Portuguese. Sydney Morning Herald, 30 July: 3.

Derriman, P. 1992. Creole echoes from our past. Sydney Morning Herald, 9 May: 42.

Elkin, A. P. 1975. Review of 'Taruru'. Oceania 45(3): 244. doi.org/ 10.1002/j.1834-4461.1975.tb01861.x.

Hale, K. L. 1971. Review of C. G. von Brandenstein's (1970) 'Narratives from the North-West of Western Australia in the Ngarluma and Jindjiparndi Languages, Volumes 1-3'. American Anthropologist 73: 1368-9. doi.org/10.1525/aa.1971.73.6.02a00610.

Hale, K. L. 1982. Ngarluma dictionary and sentences. Unpublished ms.

Heath, J. 1984. Review of 'Names and Substance of the Australian Subsection System’. Language 66: 466-7.

Jorion, P. 1983. Review of 'Names and Substance of the Australian Subsection System'. Man 18(4): 793-4. doi.org/10.2307/2801915.

McConvell, P. 1985. Time perspective in Aboriginal Australian culture: Two approaches to the origin of subsections. Aboriginal History 9(1): 53-80. 
Morphy, H. 1979. Review of L. R. Hiatt's (1978) 'Australian Aboriginal Concepts'. Mankind 12(1): 77.

Nash, D. G. 1982. Review of C. G. von Brandenstein's (1980) 'Ngadjumaja: An Aboriginal language of south-east Western Australia'. Australian Journal of Linguistics 2(2): 270-6.

Prichard, K. S. 1974. Brumby Innes and Bid Me to Love. Sydney: The Currency Press.

Thieberger, N. 1993. Handbook of WA Aboriginal Languages South of the Kimberley Region. Series C-124. Canberra: Pacific Linguistics.

Thieberger, N. 2008. Language is like a carpet: Carl-Georg von Brandenstein and Australian languages. In Encountering Aboriginal Languages: Studies in the history of Australian linguistics, (ed.) W. M. McGregor, pp. 321-35. Canberra: Pacific Linguistics.

von Brandenstein, C. G. 1934. Kultische Texte in hethitischer und churrischer Sprache. Berlin: Staatliche Museen zu Berlin, Vorderasiatische Abteilung.

von Brandenstein, C. G. 1965. Interim report on fieldwork in north-west Western Australia, 15 July - 15 August 1965. Report to Australian Institute of Aboriginal Studies, Canberra.

von Brandenstein, C. G. 1967. The language situation in the Pilbara: Past and present. Papers in Australian Linguistics (2)(A-11): 1-20.

von Brandenstein, C. G. 1968. Some new aspects of Australian Aboriginal language based on fieldwork in north-west Western Australia, 196467. Paper read at the General Meeting of the Australian Institute of Aboriginal Studies, Canberra. Typescript.

von Brandenstein, C. G. 1970a. The meaning of section and section names. Oceania 41(1): 39-49. doi.org/10.1002/j.1834-4461.1970. tb01114.x.

von Brandenstein, C. G. 1970b. Narratives from the North-West of Western Australia in the Ngarluma and Jindjiparndi Languages. Volumes 1-3. [Audio disc.] Canberra: Australian Institute of Aboriginal Studies. 
von Brandenstein, C. G. 1972. The symbolism of the north-western Australian zigzag design. Oceania 42(3): 223-38. doi.org/10.1002/ j.1834-4461.1972.tb00315.x.

von Brandenstein, C. G. 1977. Aboriginal ecological order in the southwest of Australia: Meaning and examples. Oceania 47(3): 169-86. doi.org/10.1002/j.1834-4461.1977.tb01286.x.

von Brandenstein, C. G. 1978. Identical principles behind Australian totemism and Empedoclean 'philosophy'. In Australian Aboriginal Concepts, (ed.) L. R. Hiatt, pp. 134-45. Canberra: Australian Institute of Aboriginal Studies.

von Brandenstein, C. G. 1980. Ngadjumaja: An Aboriginal language of south-east Western Australia. Innsbruck, Austria: Institut für Sprachwissenshaft der Universität Innsbruck.

von Brandenstein, C. G. 1982. Names and Substance of the Australian Subsection System. Chicago: University of Chicago Press.

von Brandenstein, C. G. 1989. The first Europeans on Australia's west coast. Typescript.

von Brandenstein, C. G. 1994. Early history of Australia: The Portuguese colony in the Kimberley: Exploration - occupation - dissolution vacation. Typescript.

von Brandenstein, C. G. n.d. [c. 1990?]. The Yawuji-bara and YawujiBaia: Two intermarrying groups of an Afro-Australian islander tribe. Typescript.

von Brandenstein, C. G. and Thomas, A. P. 1974. Taruru: Aboriginal song poetry from the Pilbara. Adelaide: Rigby.

Wordick, F. J. F. 1982. The Yindjibarndi Language. No. C-71. Canberra: Pacific Linguistics.

Yallop, C. 1974. Review of papers in 'Australian Linguistics' No. 2. by C. G. von Brandenstein, A. Capell and K. Hale. Oceania 45(1): 86. doi.org/10.1002/j.1834-4461.1974.tb01840.x.

Yengoyan, A. 1984. Review of 'Names and Substance of the Australian Subsection System'. Anthropological Linguistics 26(3): 345-9. 
This text is taken from German Ethnography in Australia, edited by Nicolas Peterson and Anna Kenny, published 2017 by ANU Press, The Australian National University, Canberra, Australia.

dx.doi.org/10.22459/GEA.09.2017.17 